\title{
PENGGUNAAN BATANG NAPIER PADA OPERASI PERKALIAN SISWA KELAS II SD GMIT ENDE 4
}

\author{
Juwita Merdja ${ }^{1}$, Agnes Pendy ${ }^{2}$ \\ ${ }^{1}$ Universitas Flores,Jln. Samratulangi Ende Flores Nusa Tenggara Timur \\ 2Universitas Flores, Jln. Samratulangi Ende Flores Nusa Tenggara Timur \\ Email: merdjajuwita@gmail.com
}

\begin{abstract}
The purpose of this study was to improve the learning outcomes of the multiplication count operation using the props of the Napier rods in grade II SD GMIT Ende 4. The type of research used is a classroom action research with research subjects were all students of grade II SD GMIT as many as 30 people with the research object is a Napier stick. This research was conducted in two cycles. The data collected in this study were student learning outcomes obtained through tests in the form of essay questions and documentation. Data were analyzed using qualitative descriptive analysis. The results of the study showed an increase in student learning outcomes in performing multiplication operation using Napier rods in grade II SD GMIT Ende 4. This was seen from the learning outcomes of the cycle I to cycle II with an average value of 55.7 and 77.67. In addition, 19 students who scored below the KKM were 16 students who scored above the KKM.
\end{abstract}

Keywords: Multiplication Operation; Napier Rods; Learning Outcomes

\begin{abstract}
Abstrak
Penelitian ini bertujuan untuk meningkatkan hasil belajar siswa dalam melakukan operasi perkalian menggunakan alat peraga batang napier pada siswa kelas II SD GMIT Ende 4. Jenis penelitian yang digunakan adalah penelitian tindakan kelas dengan subjek penelitian yaitu seluruh siswa kelas II SD GMIT sebanyak 30 orang dengan objek penelitian adalah batang napier. Penelitian ini dilaksanakan dalam dua siklus. Data yang digunakan diperoleh dari tes hasil belajar siswa yang diperoleh melalui tes dalam bentuk soal essay dan dokumentasi. Analisis data menggunakan analisis deskriptif kualitatif. Hasil penelitan menunjukkan adanya peningkatan hasil belajar siswa dalam melakukan operasi perkalian menggunakan batang napier pada siswa kelas II SD GMIT Ende 4. Hal itu dilihat dari hasil belajar siklus I sampai siklus II yang meningkat dari nilai rata rata 55,7 menjadi 77,67. Selain itu dari 19 orang siswa yang nilai dibawah KKM sebanyak 16 orang telah mendapatkan nilai diatas KKM.
\end{abstract}

Kata kunci: Operasi Perkalian; Batang Napier; Hasil Belajar

\section{PENDAHULUAN}

Pendidikan merupakan suatu kegiatan yang penting dalam menunjang pembangunan dan bagi kehidupan manusia, karena pendidikan mendorong dan menentukan majumundurnya proses pembangunan dalam segala bidang. Maka pendidikan berupaya meningkatkan sumber daya manusia sehingga pendidikan mampu meningkatkan kualitas manusia dalam segala aspek kehidupan. Oleh karena itu, pendidikan berupaya untuk meningkatkan kepribadian manusia melalui potensi yang dimilikinya (Merdja \& Pendy, 2020).

Proses belajar mengajar merupakan suatu kegiatan utuh yang dapat membantu siswa dalam mewujudkan tujuannya. Kegiatan pembelajaran akan maksimal apabila semua elemen saling 
Penggunaan Batang Napier Pada Operasi Perkalian Siswa Kelas II SD GMIT Ende 4

mendukung didalam proses kegiatan tersebut. Komponen-komponen tersebut terdiri dari pengajar, peserta didik, kurikulum, metode belajar, fasiltas dan lingkungan belajar, dimana guru merupakan faktor yang berpengaruh dalam kegiatan proses belajar mengajar. Guru memiliki peran utama dalam melaksanakan kegiatan belajar mengajar, maka guru harus memikirkan dan membuat strategi belajar mengajar yang baik agar siswa benar-benar mengerti dan memahami pelajaran yang diberikan nanti. Maka dari itu sangat diperlukan model belajar yang sesuai, sehingga hasil belajar yang diperoleh sesuai dengan yang harapkan.

Peranan yang sangat penting untuk memperkenalkan ilmu pengetahuan dasar adalah di tingkat sekolah dasar. Berdasarkan teori Piaget, bahwa anak yang berusia 6 sampai 13 tahun berada dalam tahap operasional kongkret. Pada tahap operasional kongkret, siswa telah memiliki kemampuan dalam berpikir secara logis melalui objek yang bersifat kongkret (Heruman, 2007). Matematika sudah diperkenalkan dari taman kanak-kanak meskipun belum formal. Sehingga ketika masuk di pendidikan sekolah dasar mereka dapat menyelesaikan masalah yang berkaitan dengan matematika menggunakan perhitungan dan penalaran di sekolah dan juga dalam kehidupannya. Pelajaran matematika di sekolah dasar lebih menekankan pada pemahaman konsep atau ide-ide, serta logika matematika dalam menyelesaikan masalah matematika.

Permasalahannya adalah rendahnya prestasi belajar matematika menunjukkan rendahnya mutu pendidikan di Indonesia maupun internasional yang ditunjukkan dari nilai ujian sekolah maupun nilai ujian nasional yang mengalami penurunan. Penurunan hasil belajar siswa dipengaruhi faktor dari luar/eksternal dan faktor dari dalam/internal (Sundayana, 2016).

Kegiatan belajar mengajar dipengaruhi oleh empat komponen penting bagi keberhasilan belajar siswa yaitu bahan belajar, suasana belajar, media, sumber belajar, serta guru sebagai subyek utama dalam pembelajaran. Proses pembelajaran sangat ditentukan dari empat komponen tersebut. Jika satu atau lebih komponen menurun maka tujuan belajar yang diinginkan tidak dapat tercapai secara maksimal. Seiring dengan perhatian semua pihak pada peningkatan mutu pendidikan, sorotan dan perhatian terhadap guru sebagai faktor yang cukup dominan peranannya dalam membangun dunia pendidikan menjadi semakin tinggi. Hal tersebut, sependapat dengan penelitian yang dilakukan oleh (Hammond, 2010), bahwa guru adalah faktor penentu keberhasilan siswa dalam belajar.

Salah satu mata pelajaran yang perlu diberikan kepada semua pesertadidik di sekolah, mulai dari taman kanak-kanak sampai sekolah menengah adalah matematika. Kenyataannya, matematika dianggap sebagai matapelajaran yang menakutkan dan mencemaskan bagi kebanyakan siswa. Oleh karena itu, dalam memberikan materi pelajaran matematika diperlukan media pembelajaran yang tepat dan sesuai dengan situasi dan kondisi siswa terutama untuk tingkat sekolah dasar.

Sebagai salah satu faktor keberhasilan dalam kegiatan pembelajaran matematika, alat peraga mempunyai peran penting dalam kegiatan pembelajaran. Penggunaannya disesuaikan dengan bahani yang diberikan sehingga penggunaan media pembelajaran dapat membantu siswa dalam memahami 
Penggunaan Batang Napier Pada Operasi Perkalian Siswa Kelas II SD GMIT Ende 4

materi pembelajaran (Azhar, 2011). Hasil observasi awal ditemukan bahwa kegiatan pembelajaran matematika pada pesertadidik kelas II SD GMIT Ende 4, guru masih menggunakan metode konvensional dan siswa hanya diam mengikuti penjelasan materi dan penyelesaian soal yang diberikan oleh guru. Hanya sebagian siswa yang memperhatikan pelajaran dan siswa yang lain sibuk melakukan aktivitas lain misalnya bercerita dengan siswa yang lain, keluar masuk kelas, tanpa memperhatikan penjelasan guru. Berdasarkan hasil interview awal yang dilakukan dengan beberapa siswa, menyatakan bahwa mereka bosan dan jenuh dengan metode pembelajaran yang digunakan oleh guru selama ini. Hal ini menjadikan mereka malas dan tidak tertarik dalam mengikuti pelajaran. Selain itu, selama observasi peneliti juga melihat dan terkesan hanya pesertadidik yang duduk dibagian depan lebih dominan dan antusias dalam mengikuti pelajaran dengan baik dan cenderung bersikap individual. Hal ini didukung dengan nilai hasil ulangan yang diperoleh siswa sebagian tidak mencapai nilai standar minimal yang ditetapkan. Oleh karena itu, diperlukan suatu cara untuk dapat memperbaiki proses pembelajaran yaitu dengan menggunakan media pembelajaran. Sehingga kegiatan pembelajaran menjadi lebih bermakna. Ibrahim, (2020), menyatakan bahwa media pembelajaran diartikan sebagai segala sesuatu yang dapat digunakan untuk menyalurkan pesan atau isi pelajaran, merangsang pikiran, perasaaan, perhatian dan kemampuan siswa, sehingga dapat mendorong proses belajar mengajar. Hal ini sejalan dengan Syukur (2008), media pembelajaran merupakan suatu alat atau perantara yang berguna untuk mempermudahkan proses belajar mengajar, dalam rangka mengefektifkan komunikasi antara guru dan siswa. Ada bermacam-mecam media pembelajaran salah satunya adalah batang napier.

John Napier merupakan orang yang pertama kali menemukan batang napier yang berasal dari Skotlandia. Batang napier dibuat berupa batang-batang yang terdiri dari angka 0 sampai dengan 9 yang disusun menjadi tabel perkalian guna membantu pesertadidik dalam berhitung perkalian dan juga pembagian. Batang napier dirancang untuk menyederhanakan dalam melakukan perhitungan dalam perkalian (Supriyadi, 2013). Didalam batang napier terdapat beberapa batang yang dapat dipisahkan dimana batang yang pertama menunjukkan indeks yang bertulis angka nol sampai dengan angka sembilan sebagai bilangan pengali, batang kedua menunjukkan kelompok hasil kali dengan angka 0 , batang ketiga menunjukkan kelompok hasil kali dengan angka 1 , dan seterusnya dimana jumlahn keseluruhannya adalah 11 batang.

Kelebihan berhitung perkalian dengan menggunakan batang napier adalah pesertadidik dapat memindahkan gambarnya dengan mudah membuat mereka sangat antusias sekali dan sangat aktif dalam memindahkan batang-batang angka tersebut telah tersusun menjadi sebuah kotak persegi (Aristiani, 2013). Sehingga pesertadidik menjadi lebih mudah dalam berhitung perkalian. Berikut adalah gambar batang napier. 


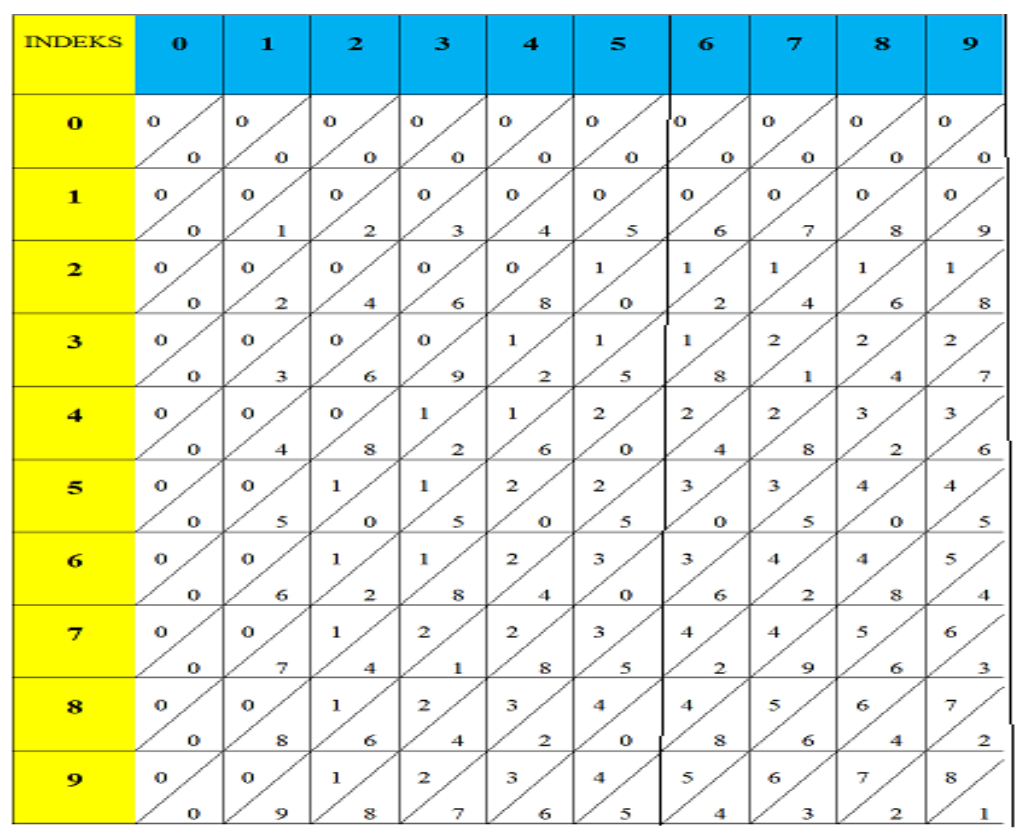

\section{Gambar 1. Tabel Batang Napier}

Menurut (Anni, 2011), hasil belajar adalah suatu proses atau terjadinya perubahan tingkah laku siswa setelah mengikuti kegiatan belajar di sekolah. Perubahan tingkah laku siswa dapat ditunjukkan dari semangat belajar, rajin mengerjkan tugas dan lain-lain. Hal ini tentu akan berpengaruh terhadap hasil belajar. Dalam penelitian ini, hasil belajar yang dilihat adalah hasil belajar pesertadidik pada materi operasi perkalian. Keberhasilan belajar dipengaruhi oleh faktor internal antara lain minat belajar, dan motivasi belajar, dan faktor eksternal merupakan keadaan yang ada dilingkungan siswa, antara lain faktor keluarga, faktor sekolah dan masyarakat serta faktor pendekatan belajar seperti guru menggunakan metode yang sesuai dalam memberikan materi pelajaran (Slameto. 2013).

Hasil penelitian (Merdja \& Pendy, 2020), menyimpulkan bahwa penggunaan batang napier pada operasi perkalian siswa kelas III Sekolah Dasar GMIT Ende 4 lebih efektif. Selain itu, hasil penelitian (Aristiani, 2013), menyimpulkan bahwa batang napier dapat meningkatkan kemampuan penggandaan angka pada anak yang sulit belajar secara signifikan.

\section{METODE}

Penggunaan Batang Napier pada siswa kelas II SD GMIT Ende 4 ini merupakan jenis Penelitian Tindakan Kelas (Classrom Action Research). Penelitian ini bertujuan untuk mengetahui hasil belajar pesertadidik pada operasi perkalian menggunakan batang napier. Penelitian dilakukan dari bulan Maret-April 2020. Subjek penelitian adalah siswa kelas II SD GMIT Ende 4 yang berjumlah 30 orang siswa. Obyek penelitian adalah Batang Napier. Desain penelitian yang digunakan adalah model Kemmis dan MC. Tagrat yaitu perencanaan (planning), tindakan (action), pengamatan 
(observing), dan refleksi (reflecting). Berikut desain penelitian tindakan kelas menurut Kemmis dan MC.Taggart:

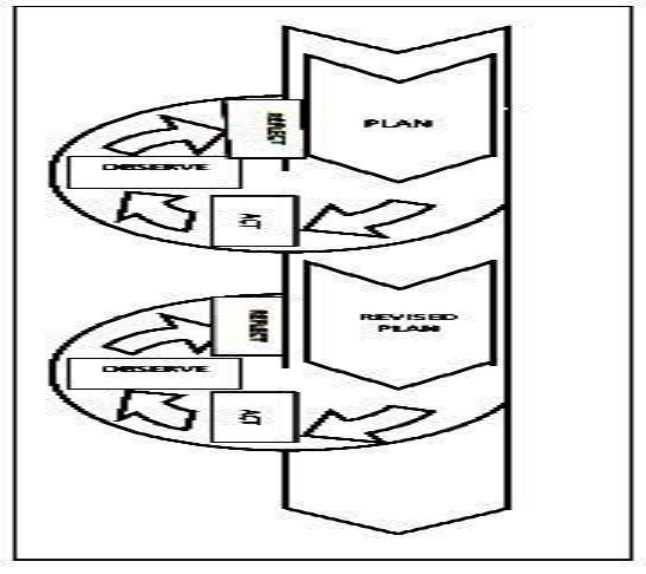

\section{Gambar 2. Desain Penelitian}

Pengumpulan data penelitian menggunakan teknik tes, dan dokumentasi. Soal tes yang diberikan berupa isian (essay test) sebanyak lima soal. Pengumpulan data melalui dokumentasi dilakukan dengan mengumpulkan dokumen-dokumen yang dimiliki oleh guru sebagai bahan yang akan digunakan untuk mengumpulkan data guna mengetahui kemampuan awal pesertadidik sebelum diberikan tindakan dalam berhitung perkalian yang berupa nilai ulangan. Kegiatan penelitian ini dilakukan dalam 2 siklus. Kegiatan survey awal dilakukan untuk mencari tahu apa saja permasalahan mengetahui permasalahan yang terjadi di dalam kelas dalam pembelajaran matematika materi operasi hitung perkalian. Berdasarkan hasil yang diperoleh pada survey awal tersebut, diketahui bahwa dalam kegiatan pembelajaran operasi hitung perkalian guru belum menggunakan batang napiersebagai alat peraga untuk membantu dalam menjelaskan materi operasi hitung perkalian. Pembelajaran dilakukan menggunakan metode konvensional saja. Dari informasi yang diperoleh saat survey awal tersebut, maka peneliti mengangkat permasalahan tersebut untuk dilakukan penelitian.

Adapun prosedur penelitian yang dilakukan sebagai berikut: Persiapan yang dilakukan oleh peneliti sebelum melaksanakan penelitian tindakan kelas ialah melakukan observasi awal untuk mengetahui permasalahan di kelas terkait dengan pembelajaran Matematika. Setelah selesai survey awal peneliti menganalisis dan menemukan solusi atau cara pemecahan masalah yaitu menggunakan Batang Napier. Kemudian peneliti menyusun instrumen penelitian yang digunakan yaitu berupa tes.

Penelitian akan dilaksanakan dalam 2 siklus. Pada siklus I direncanakan 1 kali pertemuan, begitu dengan kegiatan pada siklus ke II. Setelah selesai siklus II, peneliti akan melakukan pengambilan kesimpulan terkait dengan temuan dari penelitian yang telah dilakukan. Sebagaimana siklus I, siklus II merupakan perbaikan dari siklus I. Siklus ke 2 ini bertujuan untuk memperbaiki dan menutup kekurangan pada siklus I. Tahapan kegiatan siklus 2 sama dengan tahap pada siklus I, hanya pada siklus ke 2 lebih ditekankan pada perbaikan pada siklus I. Kegiatan yang akan 
dilaksanakan di siklus 2 yaitu menyusun rancangan kegiatan pembelajaran yang akan dilaksanakan sama seperti kegiatan sebagaimana pada siklus I. Tindakan yang dikerjakan pada siklus 2 ini adalah melaksanakann rencana yang telah dibuat untuk siklus II, yaitu memperbaiki pembelajaran Matematika pada siklus I. Observer mengamati kegiatan pembelajaran pada siklus II untuk mengetahui apakah kekurangan-kekurangan pada siklus I sudah tertutupi atau belum. Berdasarkan informasi dan juga data yang sudah dikumpulkan akan dilakukan didiskusikan terlebih dahulu untuk menentukan sudah atau belum tercapainya tujuan yang ditentukan.

Apabila sampai pada siklus II ternyata belum ada peningkatan kemampuan, maka dapat dilanjutkan pada siklus yang berikutnya. Karena hasil yang diperoleh pada kegiatan siklus II sudah meningkat maka kegiatan penelitian ini tidak dilanjutkan ke siklus berikutnya.

Penelitian ini menggunakan analisis data deskriptif dengan pendekatan kualitatif. Analisis data dilakukan agar data dapat memberikan informasi yang lebih mendalam dan bermakna sehingga dapat dibuat kesimpulan terhadap masalah yang diteliti. Dalam penelitian ini, analisis data dilakukan dengan menggunakan statistik deskiptif, yaitu mendeskripsikan data yang diperoleh melalui instrumen penelitian. Setelah data terkumpul, kemudian dilakukan analisis data dan diklasifikasikan kedalam dua kelompok data, yakni kuantitatif yang berbentuk angka-angka, sedangkan kualitatif yang berbentuk pernyataan atau simbol.

\section{HASIL DAN PEMBAHASAN}

Kegiatan belajar mengajar pada siklus I, dari hasil tes yang diberikan kepada 30 orang siswa menggunakan batang napier pada operasi hitung perkalian diperoleh nilai terendah yaitu 35 terdapat 2 orang peserta didik dan nilai tertinggi 80 yaitu 1 orang, secara lengkap ada di Tabel 1.

Tabel 1. Frequency Tabel

\begin{tabular}{|c|c|c|c|c|c|}
\hline \multicolumn{2}{|c|}{} & Frequency & Percent & Valid Percent & Cumulative Percent \\
\hline \multirow{4}{*}{} & 35 & 2 & 6.7 & 6.7 & 6.7 \\
\cline { 2 - 6 } & 40 & 4 & 13.3 & 13.3 & 20.0 \\
\cline { 2 - 6 } & 45 & 6 & 20.0 & 20.0 & 40.0 \\
\cline { 2 - 6 } & 47 & 1 & 3.3 & 3.3 & 43.3 \\
\cline { 2 - 6 } & 50 & 2 & 6.7 & 6.7 & 50.0 \\
\cline { 2 - 6 } & 55 & 4 & 13.3 & 13.3 & 63.3 \\
\cline { 2 - 6 } & 70 & 6 & 20.0 & 20.0 & 83.3 \\
\cline { 2 - 6 } & 75 & 4 & 13.3 & 13.3 & 96.7 \\
\cline { 2 - 6 } & 80 & 1 & 3.3 & 3.3 & 100.0 \\
\cline { 2 - 6 } & Total & 30 & 100.0 & 100.0 & \\
\hline
\end{tabular}


Penggunaan Batang Napier Pada Operasi Perkalian Siswa Kelas II SD GMIT Ende 4 Juwita Merdja ${ }^{1}$ Agnes Pendy ${ }^{2}$

Jupika: Jurnal Pendidikan Matematika, Volume 4. Nomor 1. Maret 2021. Hal. 62-71

Tabel 2. Descriptive Statistics

\begin{tabular}{|l|c|c|c|c|c|}
\hline & N & Minimum & Maximum & Sum & Mean \\
\hline Siklus_I & 30 & 35 & 80 & 1667 & 55.57 \\
\hline Tidak_Tuntas & 18 & 35 & 55 & 827 & 45.94 \\
\hline Tuntas & 11 & 70 & 80 & 800 & 72.73 \\
\hline Valid N (listwise) & 11 & & & & \\
\hline
\end{tabular}

Dari hasil analisa data yang terdapat pada tabel 2, diperoleh 11 orang siswa atau sebesar 37\% yang tuntas dan 19 orang siswa atau sebesar 63\% tidak tuntas dimana nilai terendah 35 dan nilai tertinggi 80 diperoleh ratarata kelas 55,57. Selengkapnya terdapat pada gambar 3 dibawah ini.

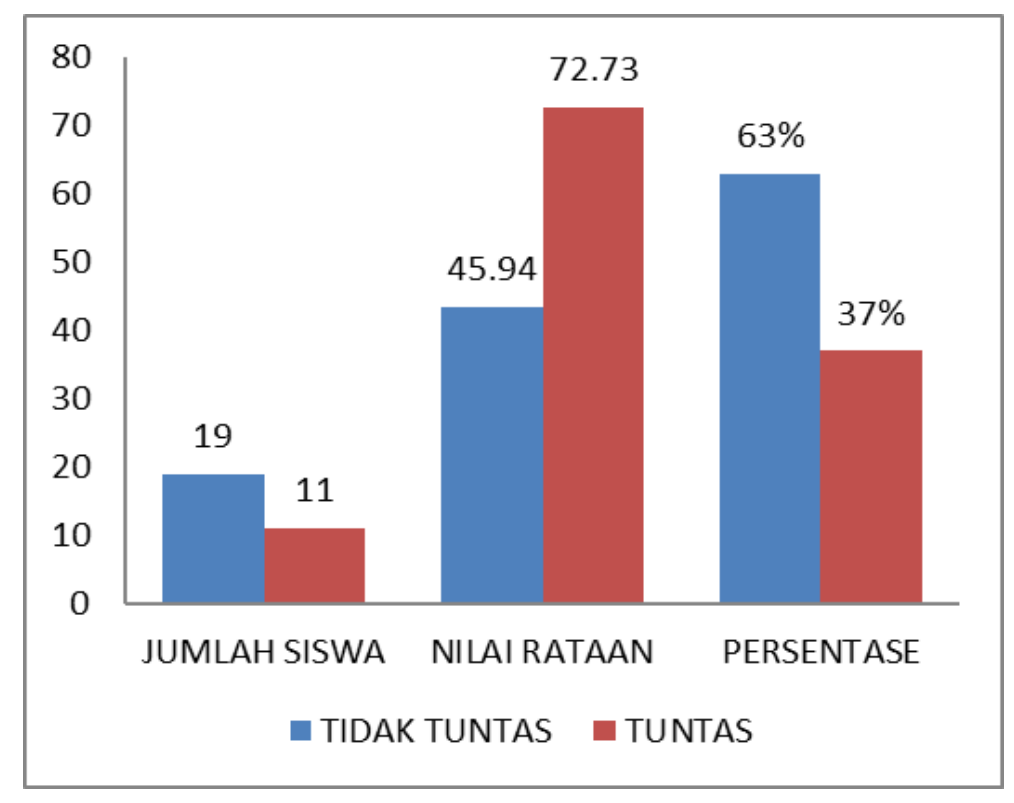

Gambar 3. Grafik Rekapitulasi Nilai Hasil Belajar Siklus I

Berdasarkan hasil yang diperoleh dari analisis data, maka peneliti menyimpulkan bahwa tingkat kemampuan siswa dalam menguasai materi menggunakan batang napier masih rendah. Oleh karena itu, kegiatan lanjut ke siklus II.

\section{a. Tahap Refleksi}

Hasil belajar dari THB siswa selama proses pebelajaran di siklus I belum dapat dikatakan sangat baik, karena masih banyak siswa yang nilai belum mencapai standar nilai yang ditentukan. Perlu ada tambahan waktu dalam pelaksanaan kegiatan pembelajaran. Maka dapat disimpulkan bahwa pembelajaran pada siklus I belum mencapai standar keberhasilan yang ditetapkan, maka penelitian ini perlu dilanjutkan ke siklus II.

\section{Siklus II}

Kegiatan belajar pada tahap II merupakan tahap perbaikan atas masalah-masalah yang ditemukan pada siklus I. Kegiatan pada tahap II langkah-langkahnya sama dengan siklus I. Soal yang diberikan berbeda tetapi tetap mengacu pada indikator yang sama. Hasil tes yang diberikan kepada 
30 orang siswa yang mengikuti kegiatan belajar operasi hitung perkalian dengan bantuan batang napier secara terperinci terdapat pada Tabel 3 berikut ini.

Tabel 3. Frequency Tabel

\begin{tabular}{|c|c|c|c|c|c|}
\hline \multicolumn{2}{|c|}{} & Frequency & Percent & Valid Percent & Cumulative Percent \\
\hline \multirow{6}{*}{ Valid } & 45 & 1 & 3.3 & 3.3 & 3.3 \\
\cline { 2 - 6 } & 50 & 1 & 3.3 & 3.3 & 6.7 \\
\cline { 2 - 6 } & 55 & 1 & 3.3 & 3.3 & 10.0 \\
\cline { 2 - 6 } & 75 & 8 & 26.7 & 26.7 & 36.7 \\
\cline { 2 - 6 } & 80 & 9 & 30.0 & 30.0 & 66.7 \\
\cline { 2 - 6 } & 85 & 8 & 26.7 & 26.7 & 93.3 \\
\cline { 2 - 6 } & 90 & 2 & 6.7 & 6.7 & 100.0 \\
\cline { 2 - 6 } & Total & 30 & 100.0 & 100.0 & \\
\hline
\end{tabular}

Berdasarkan hasil analisis data pada Tabel 3, diperoleh 3 orang pesertadidik yang tidak memenuhi standar nilai yang ditetapkan $(\mathrm{KKM})$ yaitu $\geq 60$. Dimana nilai terendah 45 sebanyak 1 orang, sedangkan 27 orang siswa yang lain memperoleh nilai yang lebih tinggi nilai standar KKM yaitu lebih tinggi dari 60. Nilai tertinggi 80 sebanyak 9 orang dan 2 orang siswa mendapatkan nilai tertinggi yaitu 90 .

Tabel 4. Descriptive Statistics

\begin{tabular}{|l|c|c|c|c|c|}
\hline & N & Minimum & Maximum & Sum & Mean \\
\hline Siklus_II & 30 & 45 & 90 & 2330 & 77.67 \\
\hline Tuntas_II & 27 & 75 & 90 & 2180 & 80.74 \\
\hline TidakTuntas_II & 3 & 45 & 55 & 150 & 50.00 \\
\hline Valid N (listwise) & 3 & & & & \\
\hline
\end{tabular}

Berdasarkan hasil analisis data deskriptif tabel 4 diatas, diperoleh 27 orang atau sebesar $90 \%$ siswa yang dapat memperoleh nilai rata-rata lebih besar dari standar nilai yang ditetapkan yaitu 80,74 dan 3 orang siswa atau sebesar 10\% siswa tidak mencapai standar nilai yang ditetapkan dengan rata-rata nilai 50. Secara detail, dapat dilihat di gambar 4 berikut ini. 


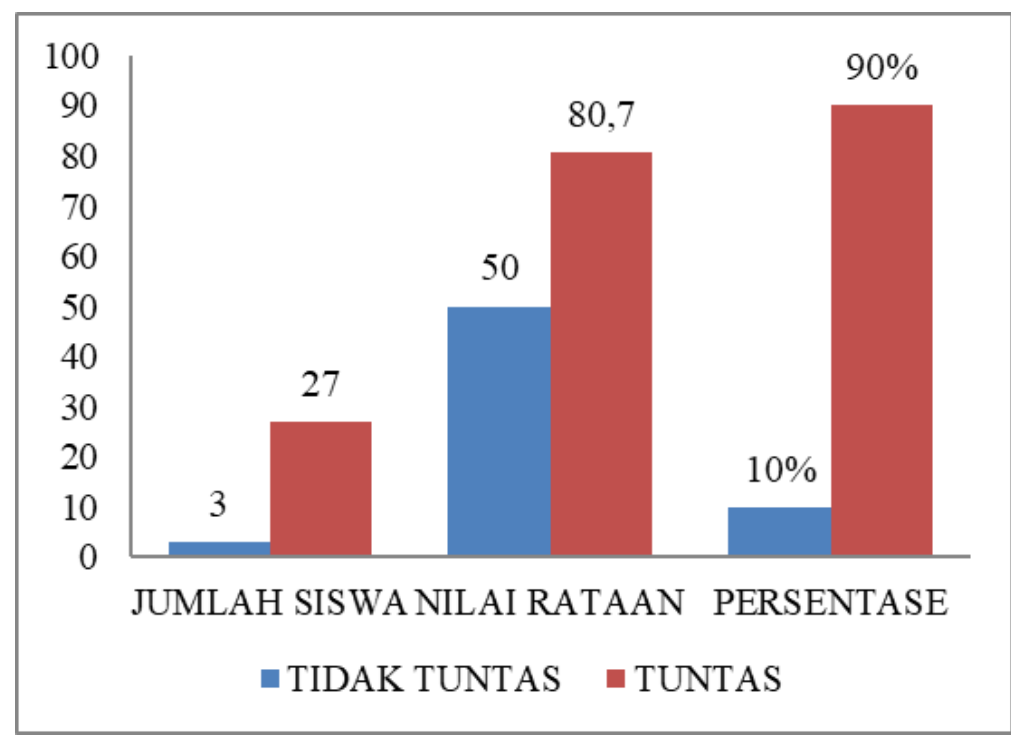

Gambar 4. Grafik Rekapitulasi Nilai Hasil Tes Siklus II

Berdasarkan hasil pada gambar 4 grafik diatas, $90 \%$ atau sebanyak 27 orang pesertadidik dapat melakukan operasi perkalian menggunakan batang napier. Sehingga dapat disimpulkan bahwa pembelajaran menggunakan batang napier pada operasi hitung perkalian dengan pada pesertadidik kelas II SD Ende 4 pada siklus ke II sudah mencapai standar keberhasilan yang ditetapkan maka kegiatan penelitian dihentikan.

\section{KESIMPULAN}

Berdasarkan hasil penelitian dan pembahasan, maka dapat diambil simpulannya yaitu hasil belajar siswa pada operasi perkalian meningkat menggunakan batang napier, hal ini dapat dilihat dari hasil belajar siklus I sebesar 37\% dengan rata-rata kelas 55,57 dan siklus II 90\% dengan rata-rata 77,67 .

\section{DAFTAR PUSTAKA}

Anni, C.T \& A.R. (2011). Psikologi Pendidikan. UPT UNNES Press.

Aristiani, N. (2013). Penggunaan Media Batang Napier dalam Meningkatkan Kemampuan Operasi perkalian Bagi Anak Kesulitan Belajar Kelas 3 SD 11 Belakang Tangsi Padang. Jurnal Ilmiah Pendidikan Khusus Vol. 1 No. 1 .

Azhar, A. (2011). Media Pembelajaran. Jakarta: PT. Raja Grafindo Persada.

Hammond, L. (2010). Evaluating Teacher Effectiveness. Retrieved September 13, 2019, from http://scale.stanford.edu/system/files/teacher_effectiveness.pdf

Heruman. (2007). Model Pembelajaran Matematika di Sekolah Dasar. Bandung: PT. Remaja Rosdakarya.

Ibrahim, R. (2010). Perancanaan Pengajaran. Jakarta: Rineka Cipta 
Penggunaan Batang Napier Pada Operasi Perkalian Siswa Kelas II SD GMIT Ende 4 Juwita Merdja ${ }^{1}$ Agnes Pendy ${ }^{2}$

Jupika: Jurnal Pendidikan Matematika, Volume 4. Nomor 1. Maret 2021. Hal. 62-71

Merdja, J. \& Pendy, A. (2020). Efektifitas Penggunaan Media Batang Napier Dalam Operasi Perkalian Terhadap Hasil Belajar Siswa kelas III SD GMIT Ende 4. Jurnal Cendekia Vol. 4 No. 2

Slameto. (2013). Belajar dan Faktor-Faktor yang Mempengaruhi. Jakarta: PT. Rineka Cipta.

Sundayana, R. (2016). Media dan Alat Peraga dalam Pembelajaran Matematika. Bandung: Alfabeta.

Supriyadi, D. (2013). Rahasia Berhitung Cepat dan Mudah Metode Batang Napier. Jakarta: Prenada Media Group.

Syukur, F. (2008). Teknologi Pendidikan. Semarang: Rasali 